\title{
Perbedaan antara Pemberian MPASI Komersil dan Buatan Rumah Tangga dengan Kejadian Perawakan Pendek pada Anak Usia 11-23 Bulan di Wilayah Kerja Puskesmas Jatinangor
}

Tisnasari Hafsah, Nisita Widyastari, Rodman Tarigan, Viramitha Kusnandi Rusmil

Departemen Ilmu Kesehatan Anak Fakultas Kedokteran Universitas Padjadjaran/RSUP Dr. Hasan Sadikin, Bandung

Latar belakang. Perawakan pendek masih menjadi masalah yang cukup serius di Indonesia. Data Riset Kesehatan Dasar (Riskesdas) Indonesia tahun 2013 menunjukkan bahwa prevalensi pendek secara nasional adalah 37,2\%. Pemilihan dan pemberian makanan pendamping ASI yang tepat berperan sangat penting demi memenuhi kebutuhan gizi anak, terutama pada 1000 hari pertama kehidupan guna mencapai pertumbuhan yang optimal.

Tujuan. Mengetahui perbedaan antara pemberian makanan pendamping ASI komersil dan buatan rumah tangga terhadap kejadian perawakan pendek pada anak usia 11-23 bulan.

Metode. Jumlah subjek penelitian adalah sebanyak 82 anak kasus dan kontrol yang dipilih menggunakan metode consecutive sampling secara berpasangan. Mengacu pada kurva pertumbuhan WHO, kasus adalah perawakan pendek yang didefinisikan sebagai anak dengan $z$-score TB/U <-2 SD dan kontrol adalah anak yang tidak pendek. Kedua kelompok dipilih secara matching berdasarkan usia dan jenis kelamin.

Hasil. Jenis pemberian makanan pendamping ASI ketika usia 9-11 bulan merupakan faktor dominan yang dapat menyebabkan perawakan pendek.

Kesimpulan. Terdapat hubungan yang bermakna antara pemberian jenis makanan pendamping ASI komersil dan buatan rumah tangga yang diberikan pada rentang usia 9-11 bulan dengan kejadian perawakan pendek pada anak usia $11-23$ bulan $(\mathrm{OR}=0,22 ; \mathrm{p}=0,01)$. Sari Pediatri 2020;21(5):295-301

Kata kunci: makanan pendamping ASI (MPASI), perawakan pendek

\section{Relationship between Commercial and Homemade Complementary Food Feeding Practice to the Incidence of Stunting in 11-23 Months Old Children in Jatinangor Community Health Clinic}

Tisnasari Hafsah, Nisita Widyastari, Rodman Tarigan, Viramitha Kusnandi Rusmil

Background. Stunting still remains a common public health problem in Indonesia. According to Basic Health Research 2013, Indonesia's stunting prevalence was $37,2 \%$. The right choice and practice of complementary feeding is crucial within the child's first 1000 days of life in order to fulfill their nutrient needs so they can achieve an optimum growth.

Objective. To discuss the possible relationship between complementary food feeding practices to the incidence of stunting in 11-23 months old children.

Methods. The subjects of this study were 82 children that had been paired for both case and control and were chosen by consecutive sampling method. According to the WHO Child Growth Standard, the case is defined as stunting which are short- statured children with height-for-age z-score <-2 SD and control is defined as non-stunted children. Both groups were being matched based on age and gender.

Result. Commercial and homemade complementary food feeding practice which was given during 9-11 months of age was the most dominant risk factor in causing the incidence of stunting.

Conclusion. There is a significant relationship between commercial and homemade complementary food feeding practice during 9-11 months of age to the incidence of stunting in 11-23 months old children (OR=0,22;p=0.01). Sari Pediatri 2020;21(5):295-301

Keywords: complementary food, stunting

Alamat korespondensi: Nisita Widyastari. Fakultas Kedokteran Universitas Padjadjaran, Jl. Prof. Eyckman No.38, Pasteur, Sukajadi, Kota Bandung, Jawa Bara 40161. Email: nisita15001@mail.unpad.ac.id 
$\mathrm{P}$ erawakan pendek masih menjadi masalah yang cukup serius di Indonesia, terutama di Jawa Barat. Berdasarkan data RISKESDAS 2013, jumlah proporsi balita pendek seIndonesia usia $12-23$ bulan sebesar 36,1\%. Data hasil pemantauan status gizi oleh Kemenkes RI tahun 2015 menunjukkan, rata-rata prevalensi balita pendek seIndonesia adalah 29\% dengan prevalensi Jawa Barat sebesar 25,6\%. ${ }^{1}$ Menurut badan kesehatan dunia WHO, prevalensi balita pendek menjadi masalah kesehatan masyarakat apabila prevalensinya $20 \%$ atau lebih. ${ }^{1}$ Dapat disimpulkan bahwa perawakan pendek masih menjadi salah satu masalah kesehatan Indonesia yang perlu ditindaklanjuti.

Pemberian nutrisi tepat dan optimal merupakan hal penting dan menjadi hak setiap anak. ${ }^{2}$ Pemberian nutrisi yang cukup, dimulai sejak lahirnya anak hingga usia dua tahun, akan menjadi dasar penentu tercapainya potensi maksimal pertumbuhan dan perkembangan anak di kemudian hari. ${ }^{2,3}$ Memasuki usia 6 sampai dengan 24 bulan, kebutuhan anak terhadap zat gizi semakin meningkat dan tidak lagi dapat dipenuhi hanya dari ASI saja. ${ }^{4,5}$ Oleh karena itu makanan pendamping selain ASI (MPASI) perlu diberikan pada saat-saat tersebut. ${ }^{4,5,6}$ Di dalam masyarakat, terdapat 2 jenis MPASI, yaitu MPASI komersil dan buatan rumah tangga. ${ }^{5}$ Kualitas MPASI buatan rumah tangga bergantung pada seberapa baik sang ibu dapat mengolah MPASI tersebut. Tidak seperti halnya MPASI komersil, yang kualitasnya sudah disesuaikan dalam standar yang disebut sebagai The Codex Alimentarius. ${ }^{7}$

Dua tahun pertama kehidupan merupakan periode $\mathrm{kritis} /$ critical window dalam memastikan bahwa anak tumbuh dan berkembang sebagaimana mestinya melalui pemberian makan yang optimal. ${ }^{2,5}$ Apabila MPASI tidak diberikan secara optimal maka anak akan cenderung memiliki risiko lebih tinggi untuk mengalami malnutrisi di awal kehidupannya. Dampak jangka panjang apabila hal tersebut terjadi adalah terhambatnya pertumbuhan linear yang lama kelamaan menjadi gagal tumbuh (growth faltering) sehingga anak berpotensi untuk mengalami perawakan pendek. ${ }^{2,4,6}$

Strategi pencegahan perawakan pendek difokuskan pada 1000 hari pertama kehidupan (HPK) karena periode ini merupakan waktu paling responsif bagi anak dalam menerima segala intervensi terkait penanggulangan gangguan pertumbuhan dan perkembangan. ${ }^{8,9}$ Mengacu kepada hal-hal di atas, peneliti ingin mengetahui perbedaan antara praktik pemberian makanan pendamping ASI komersil dan buatan rumah tangga dengan kejadian perawakan pendek pada anak usia 11-23 bulan di wilayah kerja Puskesmas Jatinangor.

\section{Metode}

Penelitian dilakukan dengan metode observasional kasus kontrol berpasangan. Penelitian ini dilaksanakan selama sebulan sepanjang bulan Agustus 2018 di seluruh posyandu dari ketujuh desa wilayah kerja Puskesmas Jatinangor. Penelitian ini dilakukan setelah mendapatkan surat izin penelitian dengan nomor 230/UN6.KEP/EC/2018 dari Komisi Etik Penelitian Fakultas Kedokteran Universitas Padjadjaran. Subjek penelitian adalah anak berusia 11-23 bulan yang datang ke posyandu ketika proses pengambilan data berlangsung. Sebagai kriteria inklusi anak diberikan ASI secara eksklusif, memiliki berat badan lahir normal, dan usia kehamilan normal. Kriteria eksklusi adalah anak dengan penyakit kronis, gangguan mental dan cacat bawaan, anak yang tidak tinggal menetap di wilayah penelitian dan ibu atau pengasuh yang membawa anak ke posyandu tidak bersedia diwawancara. Kelompok kontrol dipilih dengan proses matching berdasarkan usia dan jenis kelamin dengan kelompok kasus.

Sampel posyandu diambil menggunakan metode total sampling sementara subjek penelitian diambil menggunakan metode consecutive sampling. Anakanak yang datang ke posyandu dilakukan pengukuran antropometri meliputi, penimbangan dan pengukuran berat badan dan tinggi badan subjek menggunakan timbangan jarum tipe SECA 762, stadiometer tipe SECA 213 dan infantometer tipe SECA 210, untuk menentukan subjek kasus dan kontrol. Subjek kasus dan kontrol yang memenuhi kriteria inklusi dan eksklusi dilakukan inform consent untuk ikut serta dalam penelitian. Setelah itu dilakukan pengambilan data riwayat konsumsi jenis MPASI dan variabel lainnya dengan menggunakan kuesioner.

Variabel tergantung dalam penelitian ini adalah kejadian perawakan pendek. Mengacu pada kurva pertumbuhan anak dari WHO, subjek dikatakan memiliki perawakan pendek apabila $z$-score $\mathrm{TB} / \mathrm{U}<-2$ SD. Status tinggi atau panjang badan menurut umur ditentukan menggunakan aplikasi The MEDNEXT healthcare. 
Tisnasari Hafsah dkk: Perbedaan antara pemberian MPASI komersil dan buatan rumah tangga dengan kejadian perawakan pendek

Variabel bebas dalam penelitian ini adalah pemberian jenis MPASI. MPASI digolongkan menjadi 2 jenis, yaitu buatan rumah tangga dan komersil (buatan pabrik). Kriteria MPASI rumah tangga adalah apabila ibu membuat sendiri dengan menggunakan sumber bahan makanan sehari-hari, sedangkan kriteria MPASI komersil adalah penggunaan MPASI buatan pabrik. Apabila ibu memberikan MPASI buatan sendiri namun juga memberikan MPASI buatan pabrik (campuran) maka dikelompokkan ke dalam MPASI komersil. Variabel luar yang berpotensi memengaruhi kejadian perawakan pendek dan turut diperhitungkan dalam analisis adalah status infeksi anak, perilaku merokok orangtua dan tinggi badan ibu.

Tabel 1. Karaktersitik subjek penelitian

\begin{tabular}{|c|c|c|c|c|}
\hline Karakteristik subjek penelitian & $\begin{array}{c}\text { Pendek } \\
\mathrm{n}=41\end{array}$ & $\begin{array}{c}\text { Tidak pendek } \\
\mathrm{n}=41\end{array}$ & $\begin{array}{l}\text { Total } \\
\mathrm{n}=82\end{array}$ & Nilai p \\
\hline \multicolumn{5}{|l|}{ Karakteristik anak } \\
\hline \multicolumn{4}{|l|}{ Jenis kelamin, frekuensi (\%) ${ }^{a}$} & $1,00^{\mathrm{b}}$ \\
\hline Laki-laki & $22(54)$ & $22(54)$ & $44(54)$ & \\
\hline Perempuan & $19(46)$ & $19(46)$ & $38(46)$ & \\
\hline \multicolumn{5}{|l|}{$\begin{array}{l}\text { Status infeksi anak, } \\
\text { frekuensi (\%) }\end{array}$} \\
\hline$\geq 4$ kali & $12(32)$ & $15(39)$ & $27(35)$ & $0,69^{\mathrm{b}}$ \\
\hline$<4$ kali & $25(68)$ & $23(60)$ & $48(64)$ & \\
\hline \multicolumn{4}{|l|}{ Usia $(\%, \text { bulan })^{a}$} & $0,82^{\mathrm{b}}$ \\
\hline $11-16$ & $16(39)$ & $18(44)$ & $34(41)$ & \\
\hline $17-23$ & $25(61)$ & $23(56)$ & $48(58)$ & \\
\hline \multicolumn{5}{|l|}{ Karakteristik orangtua } \\
\hline \multicolumn{4}{|l|}{ Perilaku merokok orangtua, frekuensi (\%) } & $0,75^{\mathrm{b}}$ \\
\hline Ya & $31(76)$ & $28(70)$ & $61(73)$ & \\
\hline Tidak & $10(24)$ & $12(30)$ & $22(27)$ & \\
\hline \multicolumn{4}{|l|}{ Tinggi badan ibu, frekuensi (\%) } & $0,37^{\mathrm{b}}$ \\
\hline Pendek & $11(44)$ & $7(28)$ & $18(36)$ & \\
\hline Normal & $14(56)$ & $18(72)$ & $32(64)$ & \\
\hline \multicolumn{5}{|l|}{ Status sosial-ekonomi orangtua, ${ }^{* *}$} \\
\hline frekuensi (\%) & & & & $0,12^{\mathrm{b}}$ \\
\hline$<\mathrm{UMK}$ & $32(86)$ & $24(69)$ & $56(78)$ & \\
\hline$\geq \mathrm{UMK}$ & $5(13)$ & $11(31)$ & $16(22)$ & \\
\hline \multicolumn{4}{|l|}{ Pekerjaan orangtua (ayah), frekuensi (\%) } & $0,56^{\mathrm{b}}$ \\
\hline Tidak bekerja & $1(2)$ & $1(2)$ & $2(2)$ & \\
\hline Petani/buruh & $17(41)$ & $11(27)$ & $28(34)$ & \\
\hline Pegawai & $6(15)$ & $11(27)$ & $17(21)$ & \\
\hline Wiraswasta & $15(37)$ & $16(39)$ & $31(38)$ & \\
\hline Lainnya & $2(5)$ & $2(5)$ & $4(5)$ & \\
\hline \multicolumn{4}{|l|}{ Pendidikan ibu, frekuensi (\%) } & $0,58^{\mathrm{b}}$ \\
\hline Tamat SD & $5(12)$ & $3(7)$ & $8(10)$ & \\
\hline Tamat SMP & $15(37)$ & $17(41)$ & $32(39)$ & \\
\hline Tamat SMK/SMA & $19(46)$ & $16(39)$ & $35(43)$ & \\
\hline Tamat D1/D2/D3/PT & $2(5)$ & $5(12)$ & $7(8)$ & \\
\hline Paritas , median (Min --Maks) & $2(1-4)$ & $2(1-5)$ & - & $0,02^{\mathrm{d}^{*}}$ \\
\hline \multicolumn{5}{|l|}{ "variabel matching kelompok kasus kontrol } \\
\hline \multicolumn{5}{|l|}{${ }^{b} \mathrm{Uji}_{\text {chi square }}{ }^{\circ}$} \\
\hline \multicolumn{5}{|l|}{ 'Uji MannWhitney } \\
\hline${ }^{*}=$ signifikan $(\mathrm{p}<0,05)$ & & & & \\
\hline
\end{tabular}


Data yang telah terkumpul dianalisis menggunakan perangkat lunak statistical product and service solution (SPSS) ver.23 untuk sistem operasi Mac OS secara univariat untuk melihat distribusi serta proporsi data subjek. Analisis bivariat chi square untuk melihat perbedaan karakteristik antar kedua kelompok serta uji $M c N e m a r$ untuk menentukan odds ratio dari setiap variabel yang diduga sebagai faktor risiko terjadinya perawakan pendek. Analisis multivariat dilakukan dengan uji regresi logistik kondisional untuk mendapatkan faktor risiko dominan yang menyebabkan terjadinya perawakan pendek pada anak usia 11-23 bulan.

\section{Hasil}

Jumlah Subjek penelitian 82 anak (41 anak pendek dan 41 tidak pendek) diperoleh berdasarkan hasil penapisan status gizi dengan melakukan pengukuran antropometri (TB/U dan $\mathrm{PB} / \mathrm{U})$ di seluruh posyandu dari ketujuh desa wilayah kerja Puskesmas Jatinangor. Dalam usaha mencari kasus, didapat bahwa sebaran kasus berdasarkan desa adalah sebagai berikut,
Desa Cipacing (6 kasus), Hegarmanah (6 kasus), CikeuCikeruh (4 kasus), Sayang (9 kasus), Cibeusi (4 kasus), Cileles (2 kasus) dan Cilayung (10 kasus). Cikeruh (4 kasus), Sayang (9 kasus), Cibeusi (4 kasus), Cileles (2 kasus) dan Cilayung (10 kasus).

Sebagian besar anak yang memiliki perawakan pendek berjenis kelamin laki-laki dan berada pada rentang usia 17-23 bulan. Berdasarkan uji chi square, tidak ada perbedaan signifikan secara statistik antara status infeksi, perilaku merokok orangtua, tinggi badan ibu, status sosial ekonomi, pekerjaan orangtua dan pendidikan ibu dengan kejadian perawakan pendek ( $>0,05)$ pada kedua kelompok kasus dan kontrol. Namun, terdapat perbedaan signifikan antara paritas dengan kejadian perawakan pendek $(\mathrm{p}<0,05)$ (Tabel 1).

Berdasarkan data karakteristik subjek, sebagian besar orangtua subjek bekerja sebagai petani dan wiraswasta dengan penghasilan rata-rata kurang dari upah minimum kabupaten. Sementara dari segi pendidikan ibu, sebagian besar memiliki tingkat pendidikan sedang (SMP) dan tinggi (SMK/SMA).

Hubungan antara kejadian perawakan pendek dengan pemberian jenis MPASI dan variabel perancu

Tabel 2. Analisis McNemar status merokok orangtua, tinggi badan ibu, status infeksi anak, pemberian MP ASI 6-8 bulan, dan pemberian MPASI 9-11 bulan terhadap kejadian perawakan pendek

\begin{tabular}{|c|c|c|c|c|c|}
\hline \multirow{3}{*}{$\begin{array}{l}\text { Kasus } \\
\text { (Pendek) }\end{array}$} & \multicolumn{5}{|c|}{ Kontrol (tidak pendek) } \\
\hline & \multicolumn{5}{|c|}{ Status merokok orangtua } \\
\hline & & Merokok & Tidak merokok & $\mathrm{RO}$ & $\mathrm{p}$ \\
\hline & Merokok & 4 & 6 & 0,75 & 0,79 \\
\hline & tidak merokok & 8 & 22 & & \\
\hline & \multicolumn{5}{|c|}{ Tinggi badan ibu } \\
\hline & & Pendek & Normal & $\mathrm{RO}$ & $\mathrm{p}$ \\
\hline & Pendek & 5 & 2 & 0,4 & 0,45 \\
\hline & Normal & 5 & 2 & & \\
\hline & \multicolumn{5}{|c|}{ Status infeksi anak } \\
\hline & & $\geq 4$ kali & $<4$ kali & $\mathrm{RO}$ & $\mathrm{p}$ \\
\hline & $\geq 4$ kali & 3 & 7 & 0,63 & 0,48 \\
\hline & $<4$ kali & 11 & 13 & & \\
\hline & \multicolumn{5}{|c|}{ MPASI $6-8$ bulan } \\
\hline & & Buatan rumah tangga & Komersil & $\mathrm{RO}$ & $\mathrm{p}$ \\
\hline & Buatan rumah tangga & 11 & 10 & 0,76 & 0,67 \\
\hline & Komersil & 13 & 7 & & \\
\hline & \multicolumn{5}{|c|}{ MPASI $9-11$ Bulan } \\
\hline & & Buatan rumah tangga & Komersil & $\mathrm{RO}$ & $\mathrm{p}$ \\
\hline & Buatan rumah tangga & 14 & 6 & 0,35 & $0,03^{*}$ \\
\hline & Komersil & 17 & 4 & & \\
\hline
\end{tabular}

*= signifikan $(\mathrm{p}<0,05)$ 
Tisnasari Hafsah dkk: Perbedaan antara pemberian MPASI komersil dan buatan rumah tangga dengan kejadian perawakan pendek

Tabel 3. Faktor yang berpengaruh terhadap kejadian perawakan pendek berdasarkan model regresi logistik kondisional

\begin{tabular}{lcccc}
\hline Model & Model dan Variabel & Nilai $\mathrm{p}^{1}$ & $\mathrm{RO}^{* *}$ & IK (95\%) \\
\hline Model 1 & MPASI 6-8 bulan & 0,42 & 1,58 & $0,51-4,87$ \\
& MPASI 9-11 bulan & $0,01^{*}$ & 0,22 & $0,06-0,78$ \\
& Perilaku merokok orangtua & 0,81 & 0,87 & $0,27-2,78$ \\
& Status infeksi anak & 0,29 & 0,64 & $0,28-1,46$ \\
Model 2 & Tinggi badan ibu & 0,44 & 0,82 & $0,50-1,35$ \\
& MP ASI 6-8 bulan & 0,39 & 1,62 & $0,53-4,90$ \\
& MP ASI 9-11 bulan & $0,02^{*}$ & 0,26 & $0,81-0,85$ \\
\hline
\end{tabular}

${ }^{1}$ Uji regresi logistik kondisional; ${ }^{*}=$ signifikan $(\mathrm{p}<0,05) ;{ }^{* *}=$ adjusted odd ratio

yang dianalisis menggunakan uji McNemar (Tabel 2). Dari seluruh variabel yang dianalisis, hanya pemberian jenis MPASI pada usia 9-11 bulan saja yang menunjukkan perbedaan bermakna $(\mathrm{p}=0,03)$.

Analisis multivariat dengan uji regresi logistik kondisional menggunakan pemodelan membandingkan nilai odds ratio pemberian jenis MPASI dengan variabel luar (perilaku merokok orangtua, status infeksi anak dan tinggi badan ibu) secara bersama-sama. Setelah mengendalikan faktor perancu, diketahui bahwa pemberian jenis MPASI yang diberikan ketika anak berusia 9-11 bulan merupakan faktor dominan penyebab perawakan pendek (Tabel 3).

\section{Pembahasan}

Penelitian ini adalah penelitian pertama di Jatinangor yang menginvestigasi pemberian jenis MPASI sebagai prediktor perawakan pendek. Masalah perawakan pendek saat ini menjadi salah satu prioritas nasional, mengingat luasnya dampak yang dapat ditimbulkan oleh perawakan pendek. ${ }^{9} \mathrm{Hal}$ ini dibuktikan dengan masuknya penurunan prevalensi balita pendek sebagai salah satu dari empat program pembangunan kesehatan Indonesia dalam periode tahun 2015-2019. ${ }^{1}$

Pemberian MPASI sebagai salah satu faktor penyebab perawakan pendek dibuktikan dengan hasil yang bermakna, khususnya periode pemberian MPASI pada usia 9-11 bulan. Pada usia ini ibu/pengasuh cenderung lebih dominan memberikan MPASI yang dibuat sendiri. Hal ini tentu saja akan memengaruhi baik atau tidaknya kualitas dari MPASI. Berdasarkan penelitian Bhutta $\mathrm{dkk}^{10}$ (2013) pemberian MPASI yang buruk merupakan faktor risiko terjadinya perawakan pendek. Kualitas MPASI yang buruk akan berdampak pada kemunculan kejadian perawakan pendek di usia dini. Penelitian Dewey dan ${ }^{11}$ serta Victora $\mathrm{dkk}^{12}$ menyatakan bahwa pada usia 6-24 bulan (periode usia MPASI) merupakan usia kerap terjadinya penurunan $\mathrm{TB} / \mathrm{U}$ atau $\mathrm{PB} / \mathrm{U}$.

Pemberian MPASI yang cukup merupakan salah satu pilar utama yang mendukung pertumbuhan dan perkembangan anak. ${ }^{3}$ Gangguan pertumbuhan pada awal masa kehidupan anak, antara lain, disebabkan karena pemberian MPASI terlalu dini, MPASI tidak mencukupi kebutuhan gizi anak, dan pola pemberian MPASI menurut usia anak yang kurang baik. Dalam pemberian makanan anak perlu diperhatikan ketepatan waktu pemberian, frekuensi, jenis, jumlah bahan makanan dan cara pembuatannya. ${ }^{13}$

Hubungan yang bermakna antara MPASI dengan kejadian perawakan pendek dibuktikan pada hasil uji McNemar yang menunjukkan bahwa setelah melalui proses matching, diketahui terdapat hubungan yang signifikan antara pemberian jenis MPASI pada rentang usia 9-11 bulan dengan kejadian perawakan pendek . Kelompok anak yang menerima pemberian MPASI jenis rumah tangga saja pada rentang usia 9-11 bulan dapat mencegah terjadinya perawakan pendek sebesar 0,35 kali dibandingkan dengan kelompok anak yang menerima pemberian MPASI jenis komersil dan campuran pada rentang usia 9-11 bulan. Temuan ini kembali diperkuat dalam analisis multivariat menggunakan uji regresi logistik kondisional, yang menunjukkan bahwa setelah mengendalikan berbagai faktor perancu yang ada, pemberian jenis MPASI yang diberikan pada rentang usia 9-11 bulan merupakan faktor dominan yang menyebabkan perawakan pendek.

Temuan anak yang diberikan MPASI jenis rumah tangga saja cenderung mencegah terjadinya perawakan pendek dibandingkan dengan anak yang 
diberikan MPASI komersil dan campuran mungkin menggambarkan bahwa pengetahuan ibu atau pengasuh terkait pengolahan MPASI buatan rumah tangga sudah cukup baik dalam memenuhi kebutuhan gizi anak. Menurut penelitian Mohsin $\mathrm{dkk}^{14}$ malnutrisi pada anak dapat dikurangi secara bermakna dengan mengedukasi orangtua terkait pembuatan MPASI yang adekuat dan aman.

Ketika anak memasuki usia 9-11 bulan, kemampuan anak untuk dapat menerima makanan sudah semakin baik dan ibu pun sudah lebih berani untuk berkreasi dalam menggunakan berbagai bahan makanan untuk membuat MPASI. Pemberian bahan makanan yang lebih beragam akan mendukung pemenuhan kebutuhan gizi anak. Bahan makanan yang biasa diolah menjadi MPASI pada usia ini biasanya berupa daging, ati, berbagai jenis sayuran, dan lain sebagainya. ${ }^{15}$ Berdasarkan penelitian Krebz $\mathrm{dkk},{ }^{16}$ terdapat hubungan asosiasi yang bermakna antara pengonsumsian daging dalam MPASI dengan penurunan risiko kejadian perawakan pendek, dan ini sudah direkomendasikan juga oleh WHO.

Namun, untuk dapat menilai hal ini lebih jauh lagi, hendaknya dilakukan penelitian lanjutan mengenai bagaimana pengolahan MPASI yang dilakukan oleh para ibu di Jatinangor, sumber bahan makanan apa saja yang digunakan oleh para ibu di Jatinangor dalam membuat MPASI, dan gagasan penelitian sejenis lainnya.

Keterbatasan dalam penelitian ini di antaranya adalah penggunaan desain kasus kontrol sebagai desain penelitian. Penelitian dengan desain ini membutuhkan wali subjek penelitian (ibu atau pengasuh dari subjek penelitian) untuk mengingat kembali paparan yang diberikan kepada anaknya di masa lalu sehingga memungkinkan untuk terjadinya recall bias. Namun demikian, penelitian desain kasus kontrol pada penelitian ini memiliki kelebihan dalam kemampuannya menganalisis hubungan sebab akibat yang terfokus pada jenis pemberian makanan pendamping ASI dengan kejadian perawakan pendek.

\section{Kesimpulan}

Kesimpulan dari penelitian yang dilakukan oleh peneliti adalah terdapat hubungan yang bermakna antara pemberian jenis makanan pendamping ASI komersil dan buatan rumah tangga yang diberikan pada rentang usia 9-11 bulan dengan kejadian perawakan pendek pada anak usia 11-23 bulan di wilayah kerja Puskesmas Jatinangor. Untuk mendapatkan hubungan yang lebih valid antara perbedaan jenis MPASI dan kejadian perawakan pendek selanjutnya dapat dilakukan penelitian dengan desain kohort.

\section{Ucapan terima kasih}

Penulis ingin berterimakasih kepada Kurnia Wahyudi, M.D.,MSc. dari Divisi Biostatistik, Departemen Ilmu Kesehatan Masyarakat, Fakultas Kedokteran, Universitas Padjadjaran serta Fatimah Az Zakiah dari Fakultas Kedokteran, Universitas Islam Bandung, atas diskusi, kritik dan sarannya seputar analisis data penelitian. Demikian pula kepada para bidan desa dan kader yang sudah turut memfasilitasi dan membantu pelaksanaan pengambilan data penelitian. Penulis menyatakan tidak ada konflik kepentingan dengan pihak-pihak yang terkait dalam penelitian ini. Penelitian ini merupakan bagian dari penelitian yang dilakukan oleh Viramitha Kusnandi Rusmil, dr., SpA, M.Kes yang mendapatkan hibah internal dari Universitas Padjadjaran.

\section{Daftar pustaka}

1. Kemkes RI-Pusat Data dan Informasi Kementerian Kesehatan RI. Situasi balita pendek Jakarta: Kemkes RI; 2016.

2. Tiwari S, Chhajer CM. Child nutrition in $21^{\text {st }}$ century. IJGHTN 2016;1:73-7.

3. Stewart CP, Iannotti L, Dewey KG, Michaelsen KF, Onyango AW. Contextualising complementary feeding in a broader framework for stunting prevention. Matern Child Nutr 2013;9:27-45.

4. Dewey KG, Adu-Afarwuah S. Systematic review of the efficacy and effectiveness of complementary feeding interventions in developing countries. Matern Child Nutr 2008;4:24-85.

5. Abeshu MA, Lelisa A, Geleta B. Complementary feeding: review of recommendations, feeding practices, and adequacy of homemade complementary food preparations in developing countries - lessons from ethiopia. Front Nutr 2016;3:41.

6. Przyrembel H. Timing of introduction of complementary food: short- and long-term health consequences. Ann Nutr Metab 2012;60(suppl 2):8-20.

7. Codex Alimentarius Comission. Guidelines on formulated complementary foods for older infants and young children: 
Tisnasari Hafsah dkk: Perbedaan antara pemberian MPASI komersil dan buatan rumah tangga dengan kejadian perawakan pendek

CAC/GL 8-1991. 2013;1-10. Diakses pada 20 Februari 2020. Didapat dari: https://www.who.int/nutrition/topics/ CF_stag_backgroundpaper_report_regulatory_environment.pdf.

8. $\quad$ Prendergast AJ, Humphrey JH. The stunting syndrome in developing countries. Paediatr Int Child Health 2014;34:250-65.

9. Dewey KG, Begum K. Long-term consequences of stunting in early life. Matern Child Nutr 2011;7(suppl 3):5-18.

10. Bhutta ZA, Das JK, Rizvi A, Gaffey MF, Walker N, Horton S. dkk. Evidence-based interventions for improvement of maternal and child nutrition: what can be done and at what cost? Lancet 2013;382;452-77.

11. Dewey KG \& Huffman SL. Maternal, infant, and young child nutrition: combining efforts to maximize impacts on child growth and micronutrient status. Food and Nutr Bull 2009;30, S187-S9.

12. Victora CG, de Onis M, Hallal PC, Blossner M, Shrimpton R. Worldwide timing of growth falter- ing: revisiting implications for interventions. Pediatrics 2010;125:e473-e80.
13. Al-Rahmad AH, Miko A, Hadi A. Kajian stunting pada anak balita ditinjau dari pemberian ASI eksklusif, MPASI, status imunisasi dan karakteristik keluarga di kota banda aceh. J Kesehat Ilm Nasuwakes 2013;6:169-84.

14. Mohsin SS, Shaikh AS, Shaikh R, Haider N, Parkash A. Knowledge attitude and practices of mothers regarding complementary feeding J Dow Univ Health Sci Karachi 2014;8:21-5.

15. Complementary Feeding for Children Aged 6-23 Months: A Recipe Book for Mothers and Caregivers. Italy: Food and Agriculture Organization fo the United Nations; 2011; 2430. Diakses pada 20Februari 2020. Didapat dari: https://www. nestlenutrition-institute.org/docs/default-source/global-dcoumentlibrary/publications/secured/nniw87.pdf.

16. Krebs NF, Mazariegos M, Tshefu A, Bose C, Sami N, Chomba $\mathrm{E}, \mathrm{dkk}$. Meat consumption is associated with less stunting among toddlers in four diverse low-income settings. Food Nutr Bull 2011;32:185-91. 